\title{
Tropospheric Products from High-Level GNSS Processing in Latin America
}

\author{
María V. Mackern, María L. Mateo, María F. Camisay, and Paola V. Morichetti
}

\section{Abstract}

The present geodetic reference frame in Latin America and the Caribbean is given by a network of about 400 continuously operating GNSS stations. These stations are routinely processed by ten Analysis Centres following the guidelines and standards set up by the International Earth Rotation and Reference Systems Service (IERS) and International GNSS Service (IGS). The Analysis Centres estimate daily and weekly station positions and station zenith tropospheric path delays (ZTD) with an hourly sampling rate. This contribution presents some attempts aiming at combining the individual ZTD estimations to generate consistent troposphere solutions over the entire region and to provide reliable time series of troposphere parameters, to be used as a reference. The study covers ZTD and IWV series for a time-span of 5 years (2014-2018). In addition to the combination of the individual solutions, some advances based on the precise point positioning technique using BNC software (BKG NTRIP Client) and Bernese GNSS Software V.5.2 are presented. Results are validated using the IGS ZTD products and radiosonde IWV data. The agreement was evaluated in terms of mean bias and rms of the ZTD differences w.r.t IGS products (mean bias $-1.5 \mathrm{~mm}$ and mean $\mathrm{rms} 6.8 \mathrm{~mm}$ ) and w.r.t ZTD from radiosonde data (mean bias $-2 \mathrm{~mm}$ and mean $\mathrm{rms} 7.5 \mathrm{~mm}$ ). IWV differences w.r.t radiosonde IWV data (mean bias $0.41 \mathrm{~kg} / \mathrm{m}^{2}$ and mean $\mathrm{rms} 3.5 \mathrm{~kg} / \mathrm{m}^{2}$ ).

\section{Keywords}

IWV $\cdot$ Radiosonde $\cdot$ SIRGAS $\cdot$ ZTD

M. V. Mackern

Consejo Nacional de Investigaciones Científicas y Tecnológicas,

Mendoza, Argentina

Facultad de Ingeniería. Universidad Nacional de Cuyo, Mendoza, Argentina

Facultad de Ingeniería. Universidad Juan Agustín Maza, Mendoza, Argentina

e-mail: vmackern@mendoza-conicet.gob.ar

M. L. Mateo $(\varangle) \cdot$ M. F. Camisay

Facultad de Ingeniería. Universidad Nacional de Cuyo, Mendoza, Argentina

Facultad de Ingeniería. Universidad Juan Agustín Maza, Mendoza, Argentina

e-mail: laura.mateo@ingenieria.uncuyo.edu.ar

\section{Introduction}

Integrated Water Vapour (IWV) plays a fundamental role in several weather processes that deeply influence human activities. Retrieving IWV content in the atmosphere can be performed in different ways using independent techniques: from the traditional ones like radiosondes and ground-based microwave radiometers, up to the recent ones based on satellite techniques. In particular, the GNSS-based tropospheric Zenith Total Delay (ZTD) estimates allow inferring IWV values with high accuracy equivalent to that expected from

P. V. Morichetti

Facultad de Ingeniería. Universidad Juan Agustín Maza, Mendoza, Argentina 
direct observational techniques, such as radiosondes and microwave radiometers (Bonafoni et al. 2013; Van Baelen et al. 2005; Calori et al. 2016). Several studies have been devoted to the use of GNSS stations for the estimation of IWV over South America. Bianchi et al. (2016) estimated

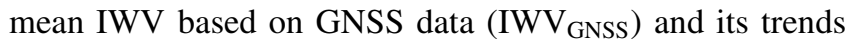
during 2007-2013 over more than a hundred GNSS tracking sites from SIRGAS-CON. Calori et al. (2016) analysed a period of 45 days where deep convective processes with hail precipitation took place over Mendoza province, in the Central-Western Argentina (CWA). For this assessment, the

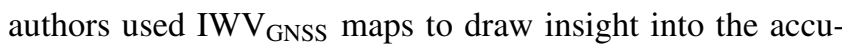
mulation and influence of humidity over the region. Even fewer studies have performed a validation of the $\mathrm{IWV}_{\mathrm{GNSS}}$; for this, Fernández et al. (2010) used radiosonde data from four locations over Central-North Argentina in order to validate IWV estimates from Global Positioning System (GPS) stations during a 1-year period (2006-2007). The

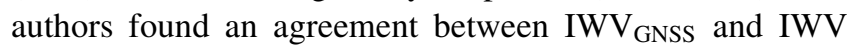
estimated through radiosonde data $\left(\mathrm{IWV}_{\mathrm{RS}}\right)$, with differences as large as $3 \mathrm{~kg} / \mathrm{m}^{2}$. Llamedo et al. (2017) used GPSderived IWV to analyse moisture anomalies over South America during El Niño-Southern Oscillation phases, finding positive anomalies over northern Argentina during El Niño events.

Camisay et al. (2020) estimated IWV $_{\text {GNSs }}$ time series for a 4-year period (2015-2018), to assess the accuracy through a comparison in two GNSS Argentinean stations with radiosonde observations and explore the role of IWV in the development of regional precipitation events over the CWA. The obtained agreement between IWV $\mathrm{GPS}_{\mathrm{G}}$ and IWV $\mathrm{V}_{\mathrm{RS}}$ was close to $2 \mathrm{~kg} / \mathrm{m}^{2}$ in terms of mean absolute error. In Latin-American region, in situ meteorological observations are scarce; therefore, GNSS atmospheric monitoring has significant relevance for the understanding of regional meteorological processes. This kind of information is extremely valuable, and it can be used to achieve a better knowledge of IWV variable in the study region.

The GNSS allows monitoring the IWV from a network that surpasses traditional techniques due to its significant temporal and spacial density. This is of interest to study the regional trends of the climatic variable for which it is necessary to have a long time series by site and region. On the other hand, the ZTD can be estimated in real-time and near real-time mode, in order to be assimilated in regional forecast models.

SIRGAS (Sistema de Referencia Geocéntrico para las Américas) is the geocentric reference frame in Latin America and the Caribbean. It is at present given by a network of about 420 continuously operating GNSS stations (Cioce et al. 2018) (Fig. 1). These stations are routinely processed by the SIRGAS Analysis Centres (AC), following the guidelines and standards set up by the International Earth Rotation and Reference Systems Service (IERS) and International GNSS Service (IGS). Since 2014, the routine GNSS data processing includes the estimation of hourly ZTD values based on GPS and GLONASS observations (Camisay et al. 2020; Sánchez et al. 2015; Brunini et al. 2012).

Pacione et al. (2017) shows the great potential that a continental GNSS network offers in atmospheric studies. EUREF Permanent Network (EPN) (Bruyninx et al. 2019) had been used as a valuable database for the development of a climate data record of GNSS tropospheric products over Europe. It had been used as a reference in the regional numerical weather prediction reanalyses and climate model simulations and had been used for monitoring IWV trends and variability. Guerova et al. (2016) showed and discussed the advantages of the application of GNSS tropospheric products in operational weather prediction and in the climate monitoring.

In this contribution, we report on the estimation and validation of the ZTD and IWV values in Latin America GNSS stations, using as input data the ZTD values obtained in: (1) the operational processing of the SIRGAS regional reference frame and (2) applying the Precise Point Positioning (PPP) approach, with two softwares, BKG NTRIP Client (BNC) and Bernese v5.2. (BSW52). To assess the reliability of our results (ZTD and IWV values), they are compared with the operational IGS products $\left(\mathrm{ZTD}_{\mathrm{IGS}}\right)$, IWV values extracted from radiosonde profiles $\left(\mathrm{IWV}_{\mathrm{RS}}\right)$ and ZTD estimations inferred from integrate the correspondent radiosonde profile data $\left(\mathrm{ZTD}_{\mathrm{RS}}\right)$.

In Sect. 2, the methodology used in operational SIRGAS processing to estimate ZTD product is reviewed. ZTD $_{\text {SIR }}$ internal consistency is presented. ZTD products estimated by PPP in SIRGAS stations are reviewed. Section 3 summarises the $Z_{\text {TDD }}$ and IWV $V_{\text {SIR }}$ products validation with respect to ZTD IGs products and IWV radiosonde data. Conclusions, outlook and future work are given in Sect. 4.

\section{$2 \quad$ Methodology}

\subsection{Estimation of ZTD Values Based on the Operational SIRGAS Processing (ZTD $\left.{ }_{\text {SIR }}\right)$}

The ZTD estimations based on the operational SIRGAS GNSS processing $\left(\mathrm{ZTD}_{\mathrm{SIR}}\right)$ are routinely calculated for all the SIRGAS-CON stations (Fig. 1) by the SIRGAS Analysis 


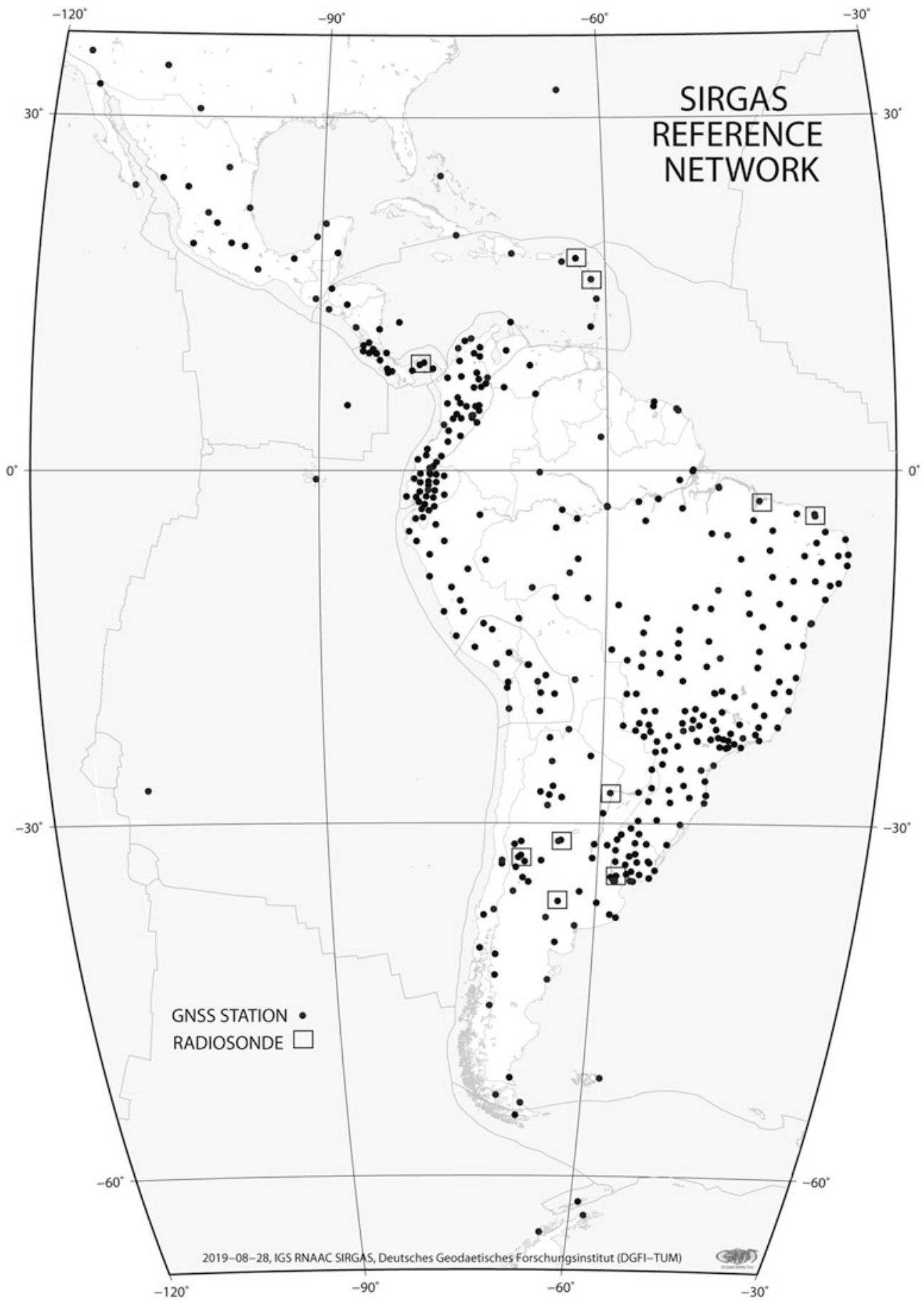

Fig. 1 SIRGAS GNSS stations and radiosonde sites considered in this study

Centres (AC) for a 5-year period (2014-2018). The eight official SIRGAS-AC (Table 1) used Bernese GNSS Software v5.2 (BSW52, Dach et al. 2015).

The SIRGAS operational ZTD products $\left(\mathrm{ZTD}_{\mathrm{SIR}}\right)$ are calculated with the final IGS products (orbits and earth rotation parameters, ERP). Table 2 summarizes the methodology implemented for the operational SIRGAS products and the testing PPP products.

Each SIRGAS-AC processes a different sub-network of SIRGAS GNSS stations. The distribution of the stations considers that each station parameter $\left(\mathrm{ZTD}_{\mathrm{i}}\right)$ is available in three different solutions, so it is possible to evaluate the 
Table 1 SIRGAS Analysis Centres (AC) that estimated ZTD for the period 2014-2018

\begin{tabular}{l|l|l|l|l|l}
\hline SIRGAS AC & Country & Institution & Software used & Start & End \\
\hline DGF & Germany & $\begin{array}{l}\text { Deutsches Geodätisches Forschungsinstitut der } \\
\text { Technischen Universität München }\end{array}$ & BSW52 & 27 Apr. 2014 & - \\
\hline ECU & Ecuador & Instituto Geográfico Militar & BSW52 & 21 Dec. 2014 & - \\
\hline IBG & Brasil & Instituto Brasileiro de Geografia e Estatistica & BSW52 & 27 Apr. 2014 & - \\
\hline IGA & Colombia & Instituto Geográfico Agustín Codazzi & BSW52 & 21 Dec. 2014 & - \\
\hline CHL & Chile & Instituto Geográfico Militar & BSW52 & 27 Apr. 2014 & - \\
\hline URY & Uruguay & Instituto Geográfico Militar & BSW52 & 27 Apr. 2014 & - \\
\hline LUZ & Venezuela & Universidad de Zulia & BSW52 & 14 Dec. 2014 & 9 Feb. 2019 \\
\hline UNA & Costa Rica & Universidad Nacional de Costa Rica & BSW52 & 1 Jan. 2014 & 29 Dec.2018 \\
\hline
\end{tabular}

Table 2 Models used for the ZTD estimation for the operational SIRGAS products and the testing PPP products

\begin{tabular}{|c|c|c|c|c|}
\hline & \multicolumn{2}{|c|}{ Operational SIRGAS processing } & \multicolumn{2}{|c|}{ Precise Point Positioning (PPP) } \\
\hline Software & \multicolumn{2}{|l|}{ BSW52 } & $\mathrm{BNC}$ & BSW52 \\
\hline Observations & \multicolumn{2}{|l|}{ GPS + GLONASS } & GPS + GLONASS & GPS \\
\hline Sampling interval & \multicolumn{2}{|l|}{$30 \mathrm{~s}$} & $\begin{array}{l}\text { Real time streams } \\
(1 \mathrm{~s})\end{array}$ & RINEX (1 s) \\
\hline Elevation cut off & \multicolumn{2}{|l|}{$3^{\circ}$} & $3^{\circ}$ & $3^{\circ}$ \\
\hline Orbits and ERP & Final IGS products & $\begin{array}{l}\text { igswwwwD.sp3 } \\
\text { igswwww7.erp }\end{array}$ & $\begin{array}{l}\text { Broadcast + IGS03 } \\
\text { correction }\end{array}$ & $\begin{array}{l}\text { Rapid (CODE) } \\
\text { CODEwwwwD.EPH } \\
\text { CODEwwwwD.ERP }\end{array}$ \\
\hline Clock correction & Final IGS products & igswwwwD.sp3 & $\begin{array}{l}\text { IGS03 stream } \\
\text { correction }\end{array}$ & $\begin{array}{l}\text { Rapid (CODE) } \\
\text { CODEwwwwD.CLK }\end{array}$ \\
\hline \multirow[t]{4}{*}{$\begin{array}{l}\text { A-priori troposphere } \\
\text { modeling and mapping } \\
\text { funtion }\end{array}$} & Pre-processing & $\begin{array}{l}\text { GMF Boehm et al. } \\
\text { (2006b) and } \\
\text { VMF Boehm et al. (2006a) }\end{array}$ & $\begin{array}{l}\text { Saastamoinen (1973) } \\
\text { dT/cos(z) }\end{array}$ & $\begin{array}{l}\text { GMF } \\
\text { Boehm et al. (2006b) }\end{array}$ \\
\hline & $\begin{array}{l}\text { Parameter } \\
\text { estimation }\end{array}$ & $\begin{array}{l}\text { VMF + gridded } \\
\text { VMF1 coefficients } \\
(00,0612 \text { and } 18 \text { UTC) }\end{array}$ & $\begin{array}{l}\text { Saastamoinen (1973) } \\
\text { dT/cos(z) }\end{array}$ & $\begin{array}{l}\text { VMF + gridded VMF1 } \\
\text { coefficients }(00,0612 \text { and } 18 \\
\text { UTC) }\end{array}$ \\
\hline & $\begin{array}{l}\text { Estimation of } \\
\text { horizontal gradients }\end{array}$ & $\begin{array}{l}\text { CHENHER model } \\
\text { Chen and Herring (1997) } \\
(24 \mathrm{~h})\end{array}$ & No & No \\
\hline & Parameter spacing & 1 or $2 \mathrm{~h}$ & Same as observation & $1 \mathrm{~h}$ \\
\hline
\end{tabular}

Table 3 Rejected ZTD estimates $\left(\sigma_{\mathrm{ZTD}}>0.02 \mathrm{~m}\right)$

\begin{tabular}{l|l}
\hline AC & Data rejected $(\%)$ \\
\hline CHL & 7 \\
\hline DGF & 0.09 \\
\hline ECU & 0.10 \\
\hline IBG & 0.06 \\
\hline IGA & 23 \\
\hline LUZ & 22 \\
\hline UNA & 0.06 \\
\hline URY & 2 \\
\hline
\end{tabular}

internal consistency and generate the final combined ZTD products $\left(\mathrm{ZTD}_{\mathrm{SIR}}\right)$.

The $\mathrm{ZTD}_{\mathrm{i}}$ variance is used as a filter $\left(\sigma_{\mathrm{ZTD}}>0.02 \mathrm{~m}\right)$, prior to the combination. The $5 \%$ of the $\mathrm{ZTD}_{\mathrm{i}}$ values are rejected in the analysed period. Table 3 shows the number of rejected estimates (in \%) for each AC.

\subsection{ZTD SIR $_{\text {Internal Consistency }}$}

Aweighted least-squares combination scheme using the inverse of the input data variances $\left(\sigma_{\mathrm{ZTD}}\right)$ as a weighting factor is implemented to estimate ZTD $_{\text {SIR }}$ products. Figure 2 shows a detail per year of the number of stations in which the $\mathrm{ZTD}_{\mathrm{i}}$ data (3 or more solutions available, with $\sigma_{\text {ZTD }}<0.02 \mathrm{~m}$ ) are combined $(\mathrm{Nc})$ compared to the number of stations that had only one solution. For the years 2015-2018 it was possible to have a data redundancy in more than $75 \%$ of the stations.

The internal consistency of the $\mathrm{ZTD}_{\mathrm{SIR}}$ values is evaluated considering the residuals of each contributing ZTD solutions with respect to the combined ZTD value $\left(Z_{T} D_{i}-Z T_{\text {SIR }}\right)$. After a weighted least squares combination process, rms

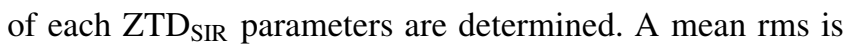
calculated per station and per year (Table 4). The mean rms 


\section{Percentage of ZTD data combined}

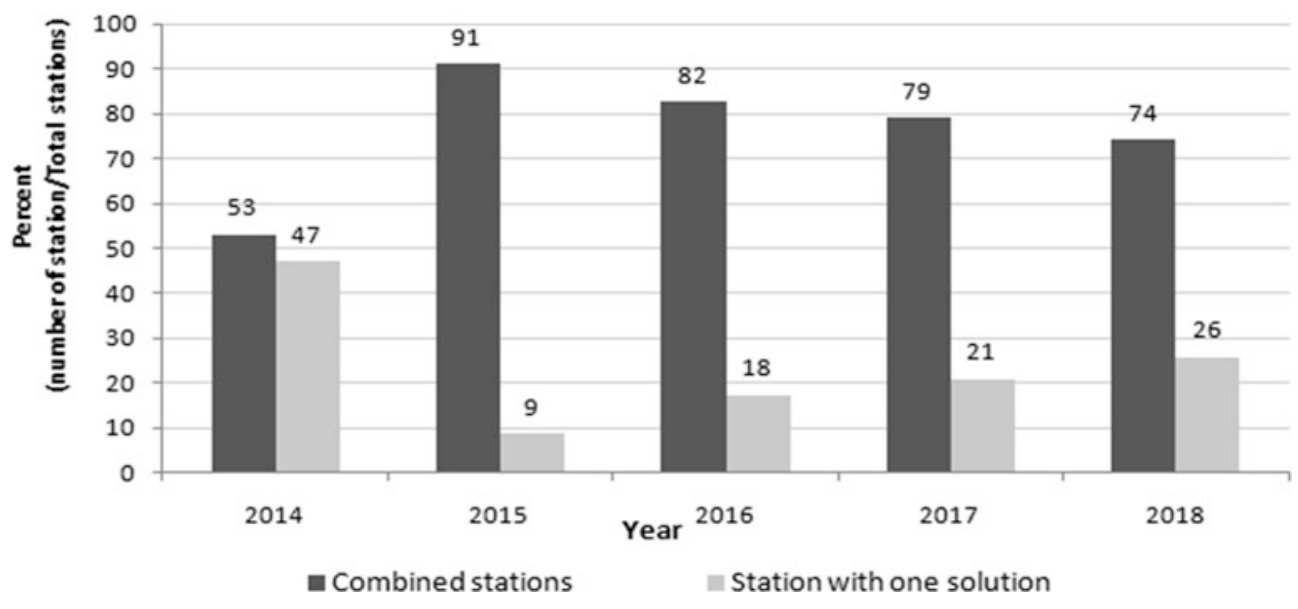

Fig. 2 Number of stations in which $\mathrm{ZTD}_{\mathrm{i}}$ data were combined vs stations with one solution

Table 4 Summary of combination process statistics

\begin{tabular}{l|l|l|l}
\hline Year & Nc/Total & $\%$ & Mean rms $[\mathrm{mm}]$ \\
\hline 2014 & $180 / 339$ & 53 & 0.15 \\
\hline 2015 & $345 / 378$ & 91 & 0.09 \\
\hline 2016 & $320 / 388$ & 82 & 0.27 \\
\hline 2017 & $308 / 390$ & 79 & 0.43 \\
\hline 2018 & $303 / 409$ & 74 & 0.54 \\
\hline
\end{tabular}

is less than $1 \mathrm{~mm}$ in more than the $84 \%$ of the estimated values in the period 2014-2018 (Fig. 3).

\subsection{ZTD $\quad$ ZTIR $_{\text {Validation with IGS Tropospheric }}$ Products}

For validation, the ZTD final products $\left(\mathrm{ZTD}_{\mathrm{SIR}}\right)$ are compared with the operational IGS (Byram et al. 2011; Byun and Bar-Sever 2009) products (ZTD IGS) at 15 GNSS stations. Figure 4 shows both ZTD time series in two selected stations, AREQ (16.46 ${ }^{\circ} \mathrm{S} ; 71.49{ }^{\circ} \mathrm{W} ; 2488.92 \mathrm{~m}$.) and OHI2 (63.32 ${ }^{\circ} \mathrm{S} ; 57.90^{\circ} \mathrm{W} ; 32.47 \mathrm{~m}$.) in the study period (Jan 2014-Dec 2018).

\subsection{ZTD $\quad$ SIR $_{\text {Validation with Radiosonde Data }}$}

$\mathrm{ZTD}_{\text {SIR }}$ also, are compared with ZTD values calculated from data of 10 radiosonde stations $\left(Z_{\mathrm{TT}}\right)$. Table 5 details characteristics of the RS used.

The $\mathrm{ZTD}_{\mathrm{RS}}$ are calculated from the precipitable water for entire sounding $\left(\mathrm{IWV}_{\mathrm{RS}}\right)$, data extracted from radiosonde profiles available at Wyoming Weather Web-University of Wyoming (http://weather.uwyo.edu/upperair/sounding. html). First, $Z_{W} D_{\mathrm{RS}}$ values were calculated by Askne and Nordius (1987) with the physical constants for atmospheric refractivity from Rüeger (2002) (Eq. 1). The mean temperature of the atmosphere (Tm) used in (1) is calculated integrating the radiosonde profiles data (temperature and dew-point) in each level profiles up to GNSS station height (Eq. 2). The zenith hydrostatic delay values at the RS sites $\left(\mathrm{ZHD}_{\mathrm{RS}}\right)$ are obtained according to Davis et al. (1985) (Eq. 3 ), where pressure is calculated to the GNSS height $\left(\mathrm{P}_{\mathrm{GNSS}}\right)$ from pressure radiosonde data. An adaptation to the standard pressure model of Berg (1948) to correct for the height differences is applied (Eq. 4). Finally, $Z_{T D} D_{R S}$ values are calculated by adding $\mathrm{ZHD}_{\mathrm{RS}}$ to $\mathrm{ZWD}_{\mathrm{RS}}$

$$
\begin{gathered}
Z W D=\frac{\left(22,9744+\frac{375463}{T m}\right) 0,4614991785}{10^{5}} I W V \\
T m=\frac{\int_{H}^{\infty} e / T d z}{\int_{H}^{\infty} e / T^{2} d z}
\end{gathered}
$$$$
Z H D=0,002276738 \cdot \frac{P_{G N S S}}{1-0,00266 \cdot \cos (2 \varphi)-0,28 \cdot 10^{-6} \cdot h_{G N S S}}
$$

$$
\mathrm{P}_{G N S S}=P_{R S}\left(1-0.0000226\left(h_{G N S S}-h_{R S}\right)\right)^{5.225}
$$

\subsection{ZTD Estimation Applying PPP}

In order to have a product in near real time to be used in numerical weather prediction model, we tested the Precise 


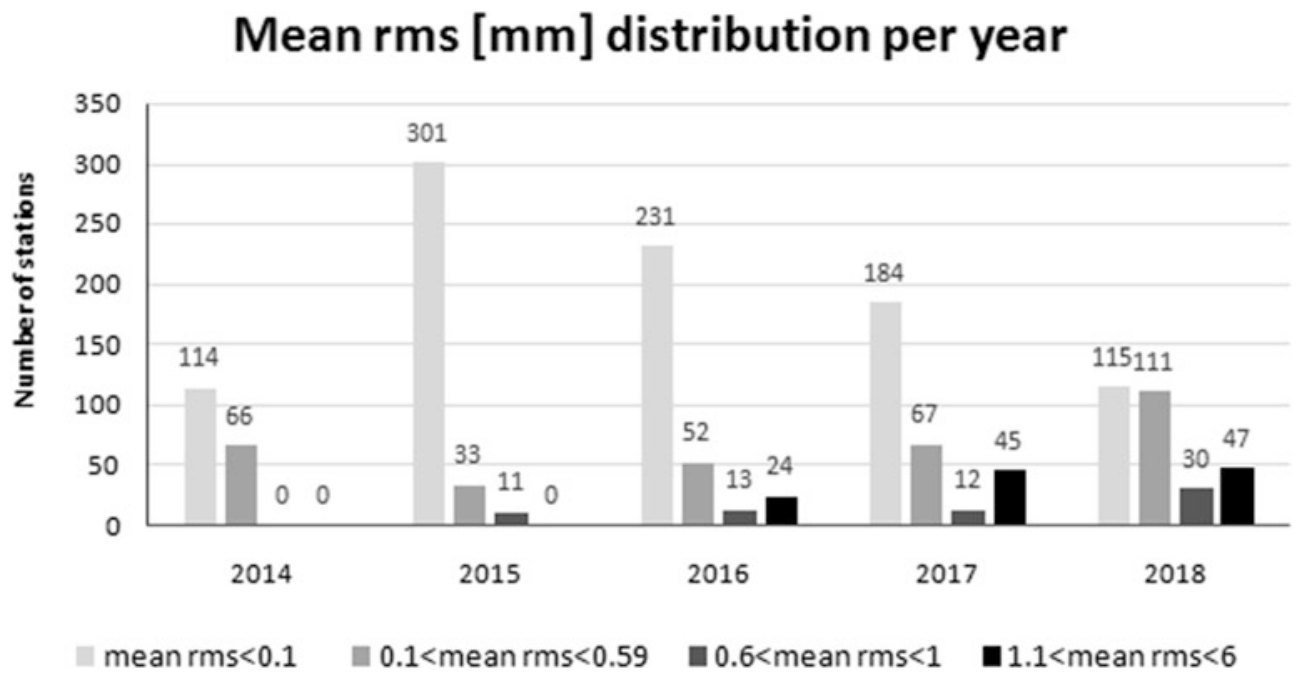

Fig. 3 Distribution of the $\mathrm{ZTD}_{\mathrm{SIR}}$ mean rms per year (2014-2018)

Point Positioning processing technique (ZTD $\left.\mathrm{ZPP}_{\mathrm{P}}\right)$. Two case of study are analysed

- Case 1: Feb 21 to Mar 27 (36 days), 2016; ten GNSS stations (located in the central-western region of South America).

- Case 2: Jan 1 to Dec. 31, 2019 (365 days); thirty GNSS stations (located in Argentina).

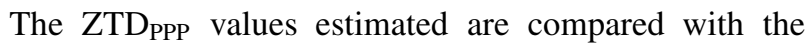
corresponding $\mathrm{ZTD}_{\mathrm{SIR}}$ values.

This estimation approached with two softwares, BNC (Weber et al. 2016) and BSW52, in the first case study. PPP with BSW52 showed better results (not shown). In the second period (year 2019) we decided to estimate ZTD only by BSW52. In both cases of study, with BSW52 PPP, rapid IGS products (orbits, ERP and satellite clock corrections) were used so the ZTD $\mathrm{ZPP}_{\text {PP }}$ were estimated with $24 \mathrm{~h}$ delay. Table 2 summarizes the input data, models and main configuration used for each software.

\subsection{Determination of IWV Values from GNSS-Based ZTD Estimates}

The GNSS-based ZTD values are used to calculate the IWV applying the ratio of Askne and Nordius (1987) to the wet component of the delay (ZWD), (Eq. 1). In this work, the ZTD $_{\text {SIR }}$ and the one from applying PPP (from BSW52) were used. ZWD values were obtained by removing the ZHD, which was calculated according to Davis et al. (1985) (Eq. 3 ). Sea level pressure values $\left(P_{r e f}\right)$ were extracted from the ERA-Interim products and were reduced to the height of the GNSS stations ( $P_{\text {GNSS }}$ ) following Berg (1948) (Eq. 5).
$P_{G N S S}=P_{r e f} \cdot\left(1-0,0000226 \cdot\left(h_{G N S S}-h_{r e f}\right)\right)^{5,225}$

In this case, the weighted mean temperature of the atmosphere $(\mathrm{Tm})$ was calculated in accordance with Mendes (1999) using the surface temperature (Ts) also provided by ERA-Interim. The values for the refractivity constants were taken from Rüeger (2002). Following this strategy, IWV $\mathrm{IIR}_{\text {SIR }}$ series from a 5 years (2014-2018) period were estimated in each SIRGAS station. We generated four daily IWV maps by Hunter (2007) (at 00:00, 06:00, 12:00 and 18:00 UTC) for the entire SIRGAS region, see some examples in Fig. 5 (24-6-2018).

The IWV $\mathrm{IIR}_{\text {SIR }}$ values were tested in the 10 radiosonde stations selected (Table 5). The Figs. 6 and 7 show the comparison of $\mathrm{IWV}_{\mathrm{SIR}}$ (inferred from $\mathrm{ZTD}_{\mathrm{SIR}}$ ) values with values obtained from radiosonde profiles $\left(\mathrm{IWV}_{\mathrm{RS}}\right.$ ) at two SIRGAS stations: MZAC (located in an arid region) and IGM1 (located in a humid region), respectively.

\section{$3 \quad$ Results}

\subsection{ZTD SIR Validation}

Our results presented a quite good agreement with the IGS products (see Fig. 4). Discrepancies between ZTD $_{\text {SIR }}$ and ZTD $_{\text {IGS }}$ values are compared at 15 IGS (SIRGAS) stations (Fig. 8). The results present a mean root mean square (rms) value of $6.8 \mathrm{~mm}(0.29 \%$ of the mean ZTD) with a negative mean bias of $1.5 \mathrm{~mm}(0.07 \%$ of the mean ZTD).

The comparison of $\mathrm{ZTD}_{\mathrm{SIR}}$ w.r.t. $\mathrm{ZTD}_{\mathrm{RS}}$ is also very promising: discrepancies computed at 10 radiosonde stations (see Fig. 1 and Table 5) have a mean rms of $7.5 \mathrm{~mm}(0.32 \%$ of the mean ZTD) and a negative mean bias of $2 \mathrm{~mm}(0.09 \%$ 

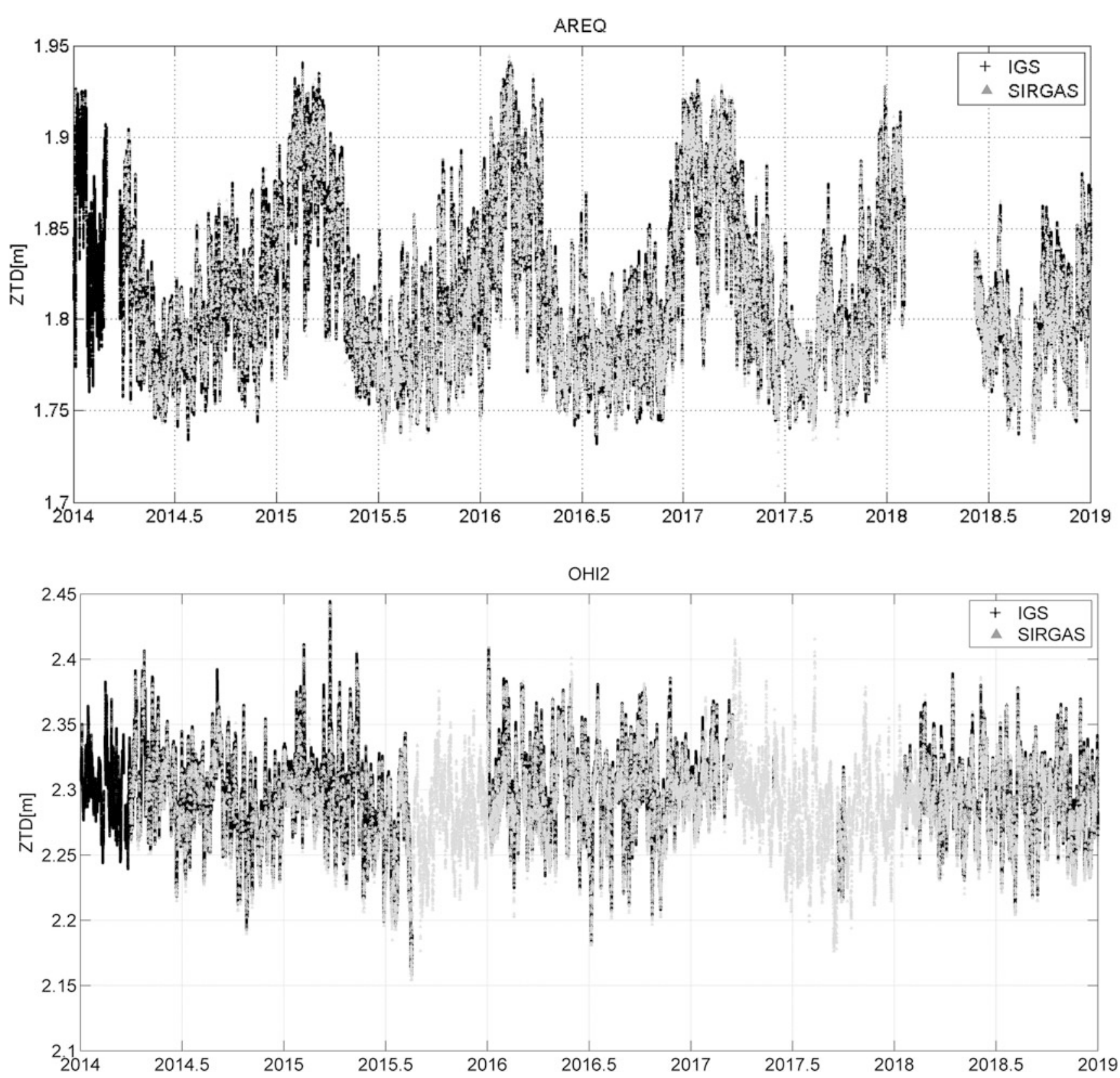

Fig. 4 Time series of $Z_{T D}$ SIR (grey) and $Z_{T D}$ IGS (black) values at two selected SIRGAS stations, AREQ (Arequipa, Peru) and OHI2 (O'Higgins, Antartica), period: Jan 2014-Dec 2018

Table 5 Location of ten RS stations used (bold used in $\mathrm{ZTD}_{\mathrm{PPP}}$ validation), distance to GNSS sites, and heights ( $\mathrm{h}_{\mathrm{GNSS}}$ and $\mathrm{h}_{\mathrm{RS}}$ )

\begin{tabular}{|c|c|c|c|c|c|c|}
\hline RS station & GNSS site & Lat. $\left(^{\circ}\right)$ & Long. $\left({ }^{\circ}\right)$ & $\mathrm{h}_{\mathrm{RS}}(\mathrm{m})$ & $\mathrm{h}_{\mathrm{GNSS}}(\mathrm{m})$ & Distance $(\mathrm{km})$ \\
\hline 78866 (TNCM) & SMRT & 18.03 & -63.09 & 9 & -32.48 & 3 \\
\hline 78897 (TFFR) & ABMF & 16.21 & -61.41 & 8 & -25.57 & 12 \\
\hline 78807 (MPCZ) & IGN1 & 8.98 & -79.46 & 19 & 47.56 & 13 \\
\hline 82280 & SALU & -2.53 & -44.28 & 51 & 18.99 & 11 \\
\hline 82397 & CEFT & -3.59 & -38.45 & 19 & 4.90 & 15 \\
\hline 87155 (SARE) & CHAC & -27.36 & -59.04 & 52 & 77.95 & 10 \\
\hline 87418 (SAME) & MZAC & -32.83 & -68.78 & 704 & 859.86 & 13 \\
\hline 87623 (SAZR) & SRLP & -36.57 & -64.27 & 191 & 223.83 & 7 \\
\hline 87344 (SACO) & CORD & -31.32 & -64.22 & 474 & 746.83 & 34 \\
\hline 87576 (SAEZ) & IGM1 & -34.65 & $-\mathbf{5 8 . 4 2}$ & 20 & 50.69 & 28 \\
\hline
\end{tabular}



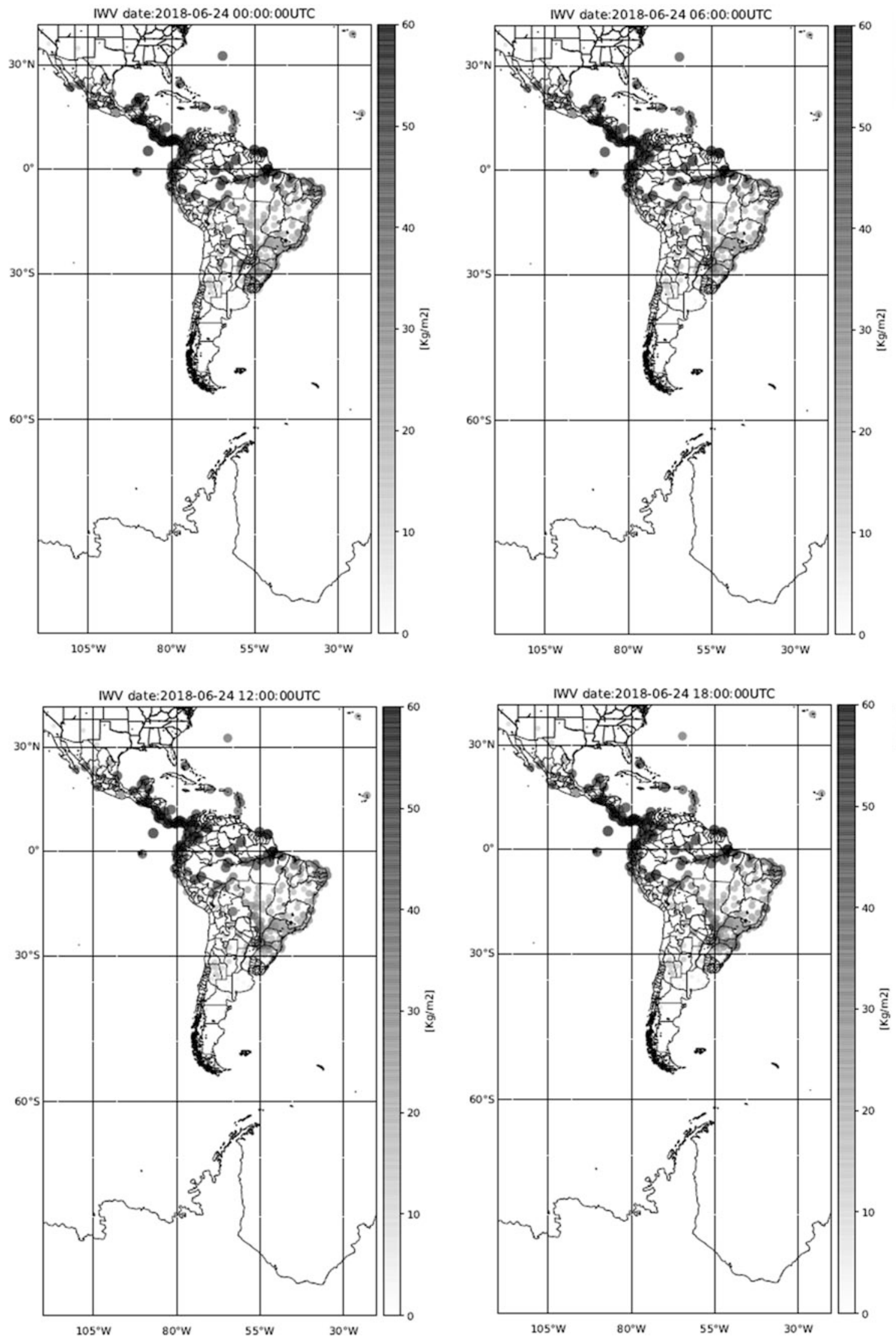

Fig. 5 Maps of IWV inferred from the ZTD estimates produced within the operational SIRGAS processing (24-6-2018; 00,06,12 and 18 hs UTC) 
Fig. $6 \mathrm{IWV}_{\mathrm{SIR}}$ (MZAC GNSS station) and IWV $V_{R S}$ (RS: SAME)

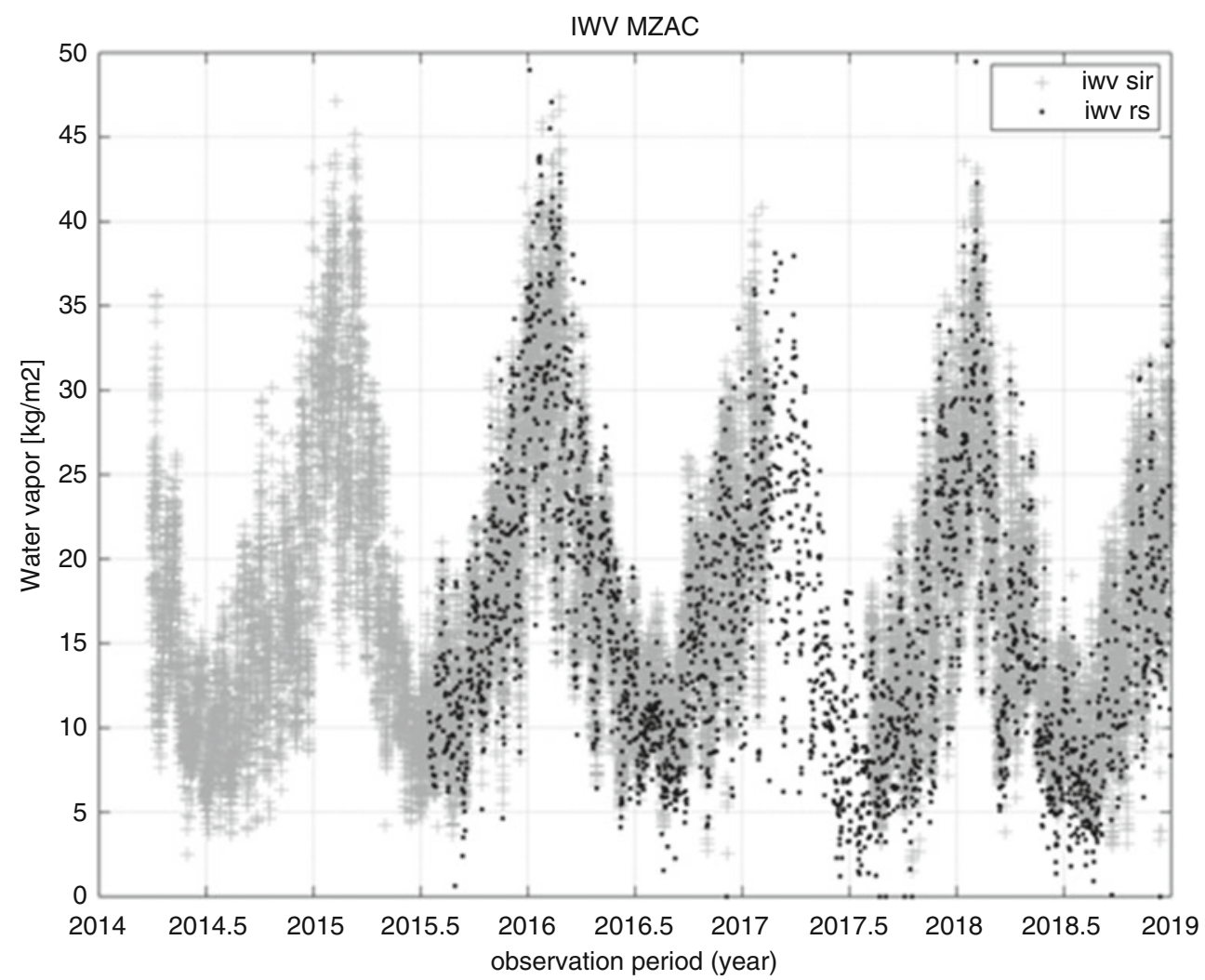

Fig. $7 \operatorname{IWV}_{\mathrm{SIR}}$ (IGM1 GNSS station) and $\mathrm{IWV}_{\mathrm{RS}}(\mathrm{RS}: \mathrm{SAEZ})$

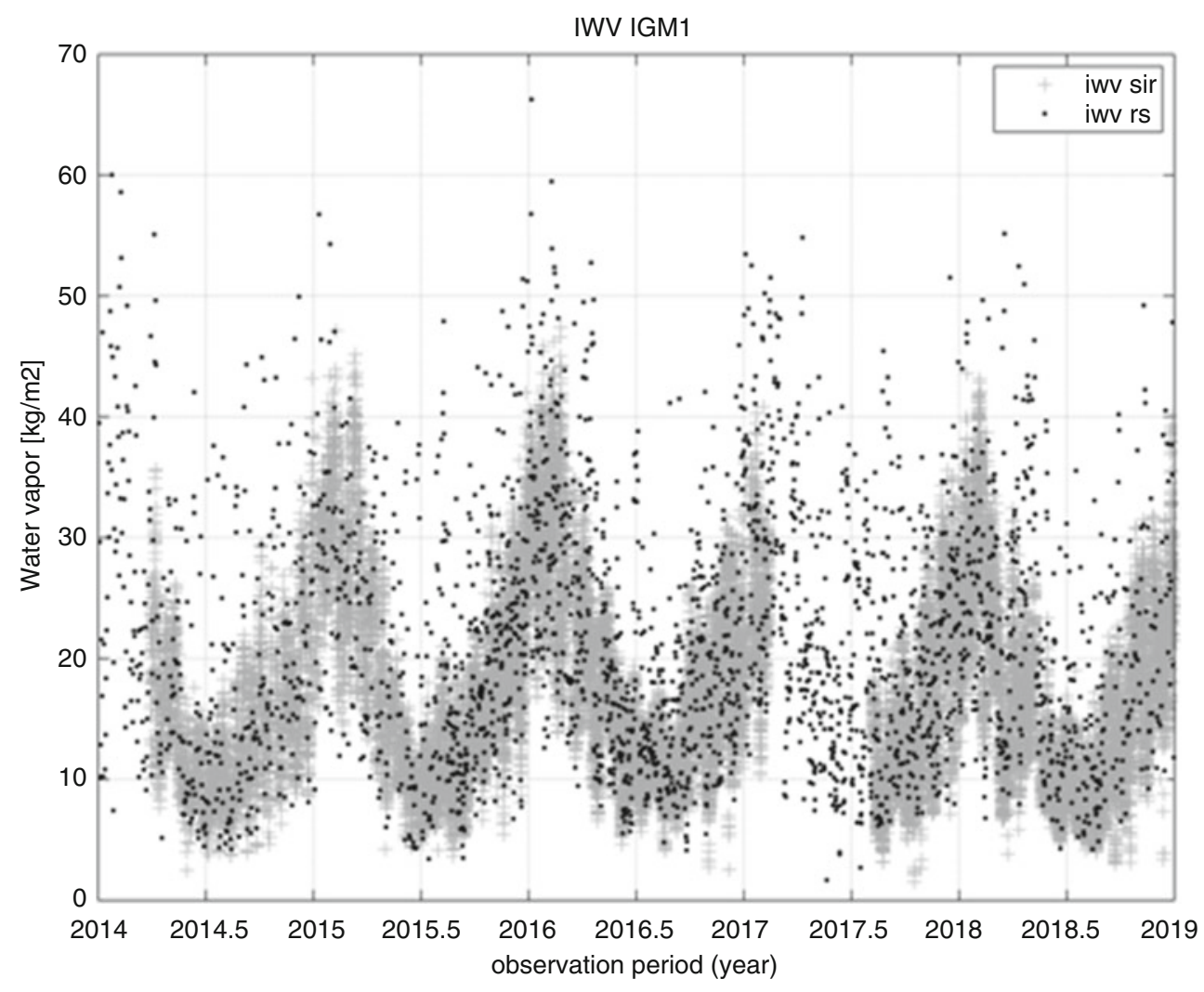




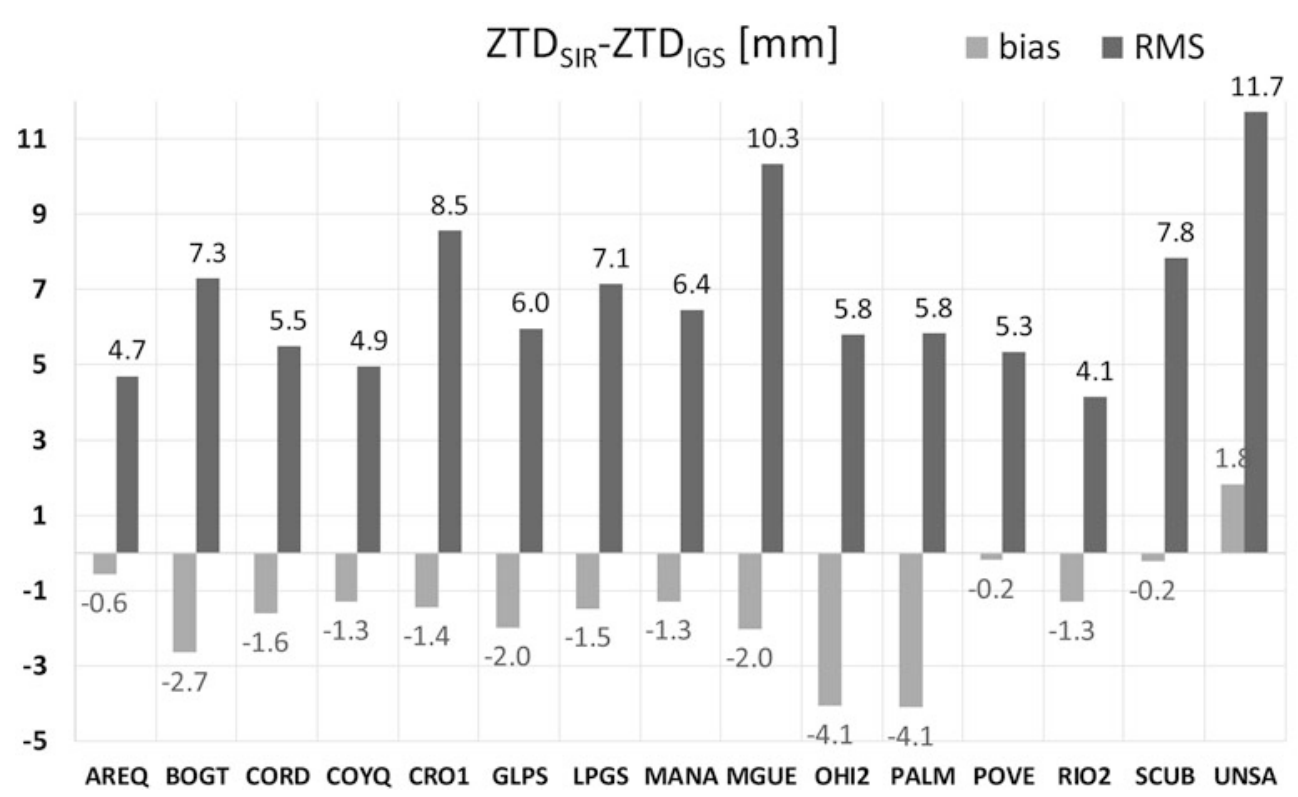

Fig. 8 Comparison of ZTD SIR $_{\text {and }}$ ZTD $_{\text {IGS }}$ values at 15 selected SIRGAS stations (Jan 2014-Dec 2018)

of the mean ZTD). An analysis of the radiosonde types has been started at each analysed site, which it could be the cause for the negative bias in line with the results of Wang et al. (2007) and Pacione et al. (2017).

\subsection{ZTD PPP Products Validation}

Analysing the ZTD ${ }_{\text {PPP }}$ products, the BSW52-based ZTD ${ }_{\text {PPP }}$ estimates showed a better agreement than the BNC-based ZTD $D_{\text {PPP }}$ estimates with respect to the corresponding ZTD $_{\text {SIR }}$ values. The rms and bias are the two indexes for the evaluation of the two estimations. Results of these two-test data set are shown in Table 6. BNC-based ZTD $\mathrm{ZPPP}_{\text {estimates were }}$ less accurate as expected because real time IGS product were used. It may also be a consequence of the fact that ZTD $_{\text {SIR }}$ and the BSW52-based ZTD PPP $_{\text {use the same models }}$ to determine the tropospheric parameters. In the case 2 a bias-reduction scheme was implemented on a monthly basis as applied in Douša and Vaclavovic (2014).

The comparison of the BSW52-based ZTD ${ }_{\mathrm{PPP}}$ estimates and ZTD $_{\text {SIR }}$ values at two selected SIRGAS station, EBYP (in a subtropical region) and MGUE (in an arid region), with the data in the case 1, are shown in Fig. 9.

The discrepancies between the ZTDPPP values estimated in the second case of study (Year 2019, 30 stations) with the respectively $\mathrm{ZTD}_{\mathrm{SIR}}$ values were also very promising (Fig. 10). The mean rms and mean bias per station is shown in the Fig. 10. The $84 \%$ of the stations had a mean $\mathrm{rms}<28 \mathrm{~mm}$ and the rest $16 \%$ had a mean rms $<31 \mathrm{~mm}$.

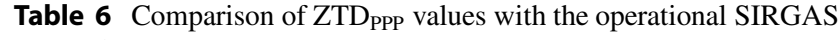
processing $\left(\mathrm{ZTD}_{\mathrm{SIR}}\right)$

\begin{tabular}{l|l|l|c}
\hline Case & Software & Bias [mm] & rms [mm] \\
\hline $\begin{array}{l}\text { Case } 1 \\
2016 \text { (36 days), 10 } \\
\text { GNSS stations }\end{array}$ & BSW52 & $49(1.8 \%$ of the ZTD $)$ & 55 \\
& & & \\
\cline { 2 - 4 } & BNC & $118(4.8 \%$ of the ZTD $)$ & 125 \\
\hline $\begin{array}{l}\text { Case } 2 \\
\text { 2019 (365 days), 30 } \\
\text { GNSS stations }\end{array}$ & BSW52 & $2(0.07 \%$ of the ZTD $)$ & 22 \\
\hline
\end{tabular}

In five GNSS stations, the BSW52-based ZTD ${ }_{\text {PPP }}$ estimates were validated with respect to $\mathrm{ZTD}_{\mathrm{RS}}$ (detailed in bold in Table 5). Figure 11 shows this comparison in the IGS (SIRGAS) station CORD in the centre of Argentina, as an example.

\subsection{IWV $\mathrm{WIR}_{\text {Validation }}$}

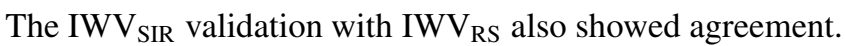
The results for a period of 5 years, in $10 \mathrm{RS}$ - GNSS locations yielded a mean bias $0.41 \mathrm{~kg} / \mathrm{m}^{2}$ and a mean rms $3.5 \mathrm{~kg} / \mathrm{m}^{2}$. The correlation coefficient of the two series $\left(\mathrm{IWV}_{\mathrm{SIR}}\right.$ and $\mathrm{IWV}_{\mathrm{RS}}$ ) presented in Fig. 12 is 0.94 , which indicates a very good agreement between both estimations.

In the other hand, the comparison of $\operatorname{IWV}_{\mathrm{PPP}}$ (calculated from the BWS52-based ZTDPPP values) with $\mathrm{IWV}_{\mathrm{RS}}$, produces discrepancies with a mean $\mathrm{rms}$ of $1 \mathrm{~kg} / \mathrm{m}^{2}$, a standard deviation of $0.73 \mathrm{~kg} / \mathrm{m}^{2}$ and a bias of $2.37 \mathrm{~kg} / \mathrm{m}^{2}$ (not shown). 

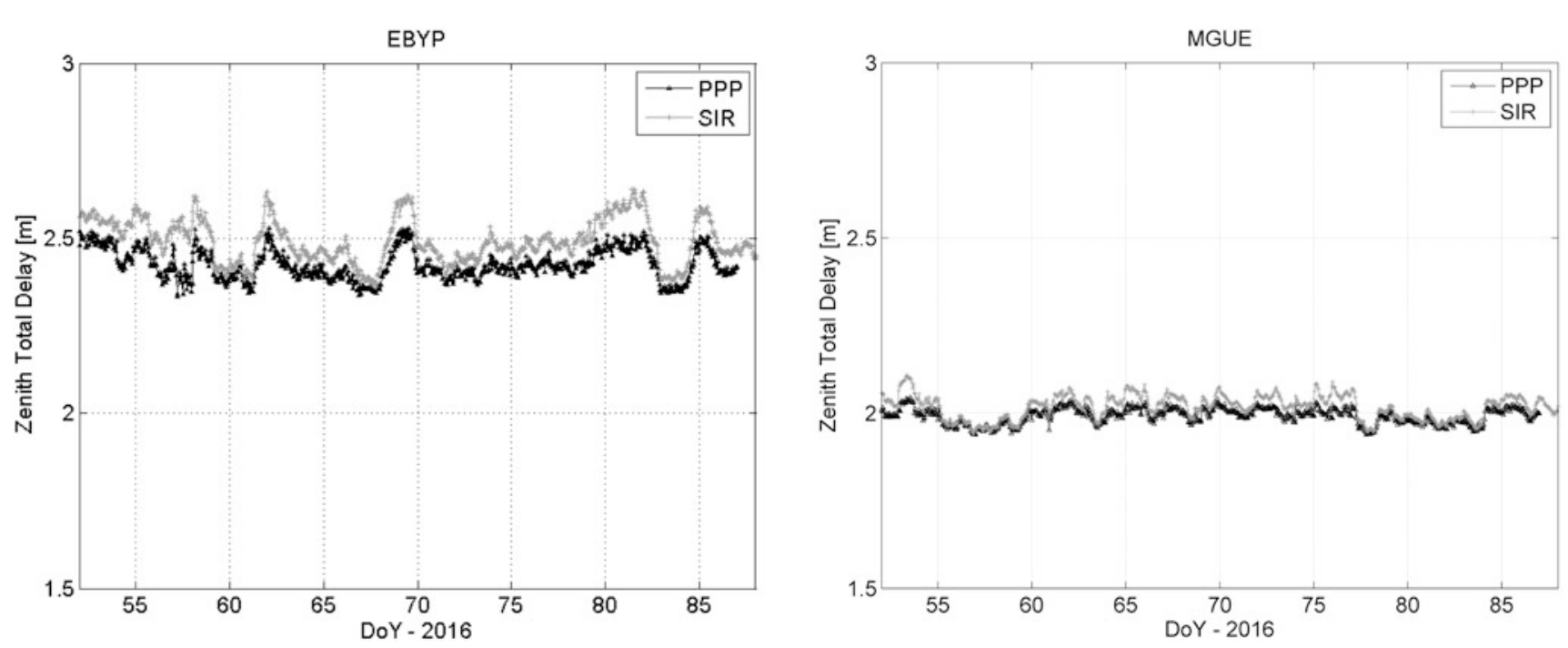

Fig. 9 Comparison of $\mathrm{ZTD}_{\mathrm{SIR}}$ and BSW52-based $\mathrm{ZTD}_{\mathrm{PPP}}$ values at two selected SIRGAS stations

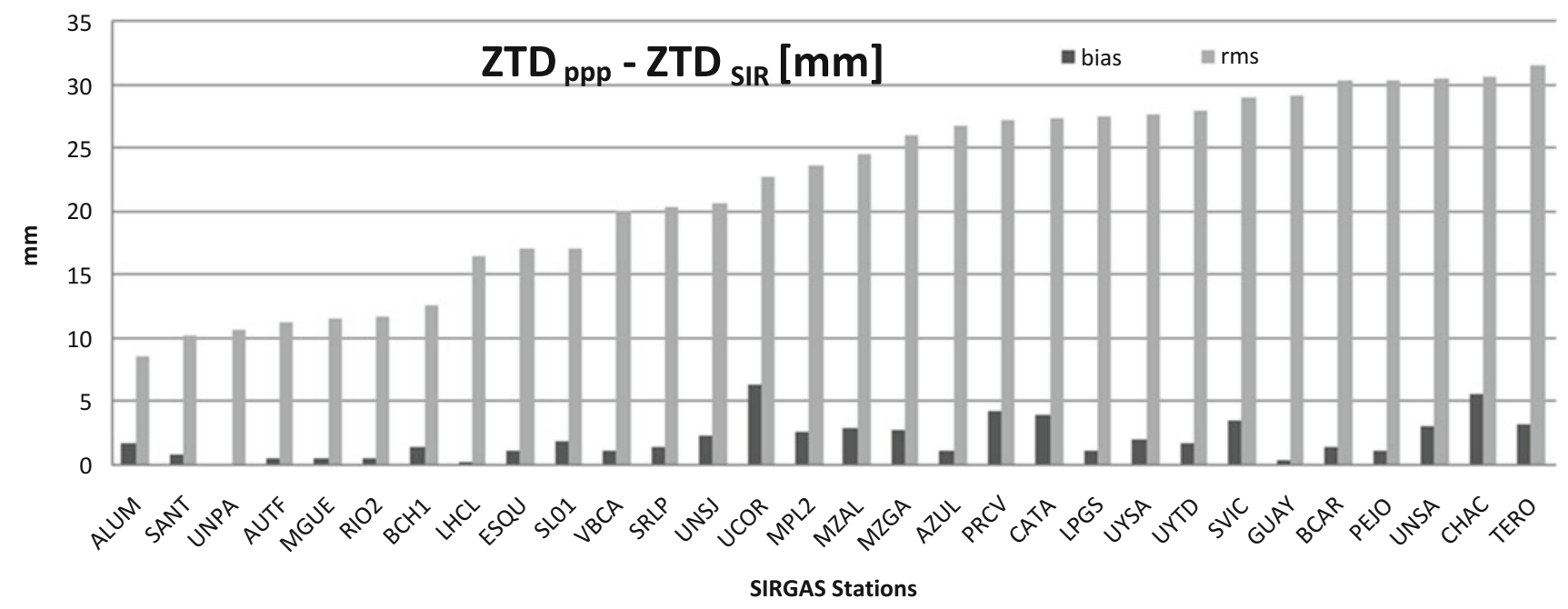

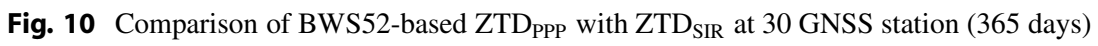

\section{Conclusions}

Latin America has SIRGAS network, an infrastructure of GNSS stations that generates ZTD (per hour), offering regional and continental coverage that can be used in atmospheric studies.

The internal consistency of the $\mathrm{ZTD}_{\text {SIR }}$ values, calculated by SIRGAS ACs, have been evaluated for a period of 5 years (2014-2018). An average rms less than $1 \mathrm{~mm}$, in more than the $84 \%$ of the values, indicate the rigorous weighted least squares combination process implemented to get the SIRGAS reference products.

The ZTD $_{\text {SIR }}$ series for a 5-year period have been validated with two different time series. They agree with the corresponding values of the ZTD series obtained by the IGS (mean rms $6.8 \mathrm{~mm}$; mean bias $-1.5 \mathrm{~mm}$ ) as well as those from the radiosonde technique (mean $\mathrm{rms} 7.5 \mathrm{~mm}$; mean bias $-2 \mathrm{~mm}$ ).

The ZTD obtained by PPP with BSW52, using the RAPID CODE products (ephemeris and clock corrections) are validated with respect to the post-processing products

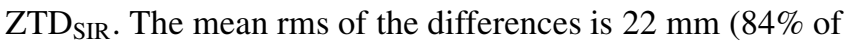
the stations had a mean rms $<28 \mathrm{~mm}$ ) for an annual case of study (2019, 30 stations). It remains to continue improving the methodology to increase accuracy and decrease the positive bias that on average resulted in $2 \mathrm{~mm}(0.07 \%$ of the ZTD mean value in the stations evaluated). Anyway, these accuracy of $\mathrm{ZTD}_{\mathrm{PPP}}$ complies with the threshold requirements for the operational NWP nowcasting - the relative accuracy of $5 \mathrm{~kg} / \mathrm{m}^{2}$ in integrated water vapor (IWV) and $30 \mathrm{~mm}$ in ZTD when approximating the conversion factor defined by Bevis 


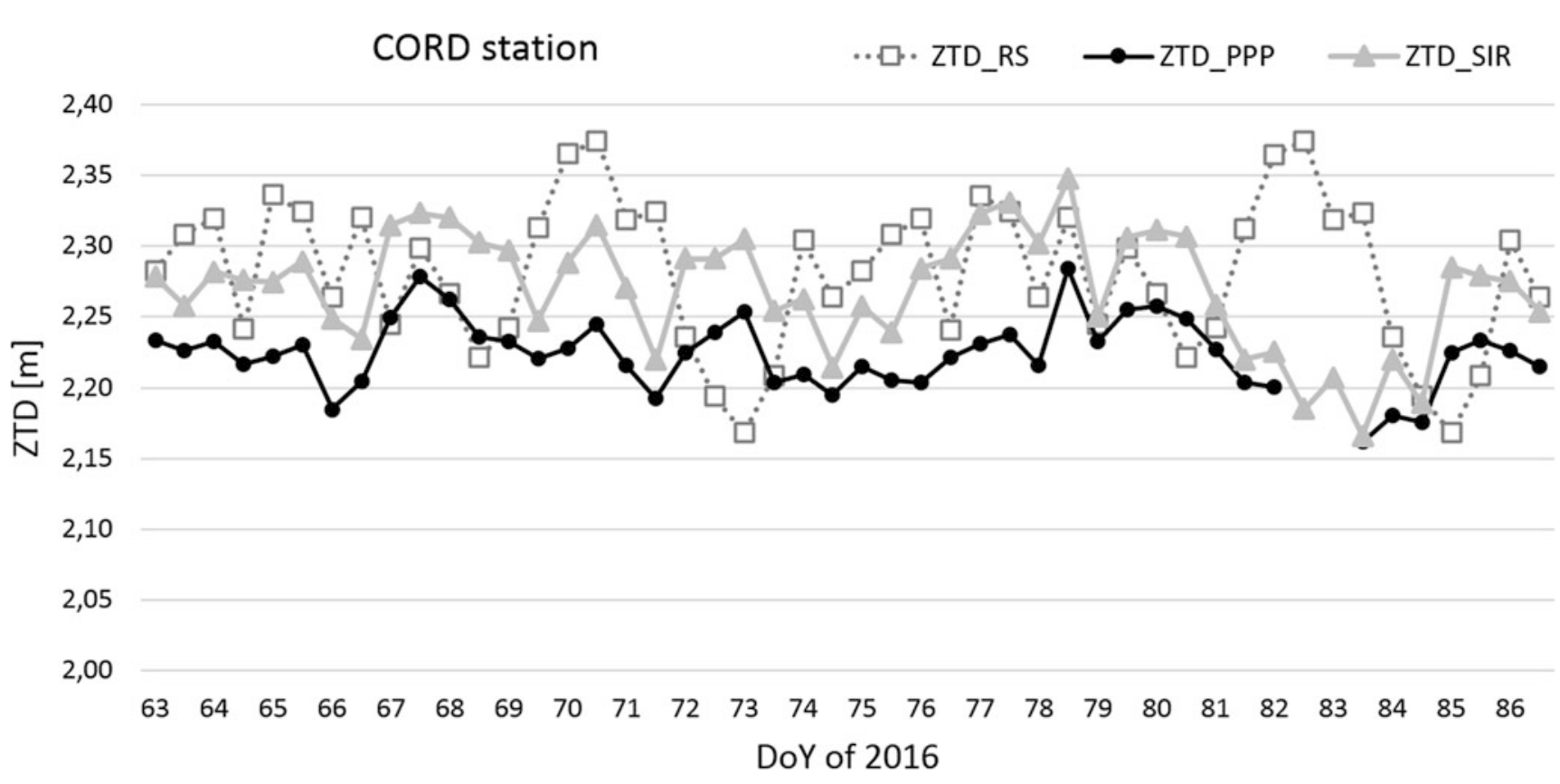

Fig. 11 Time series of $Z_{T D}$ SIR, BWS52-based ZTDPPP and $Z_{T D}$ values at a GNSS station located in Cordoba (Argentina)
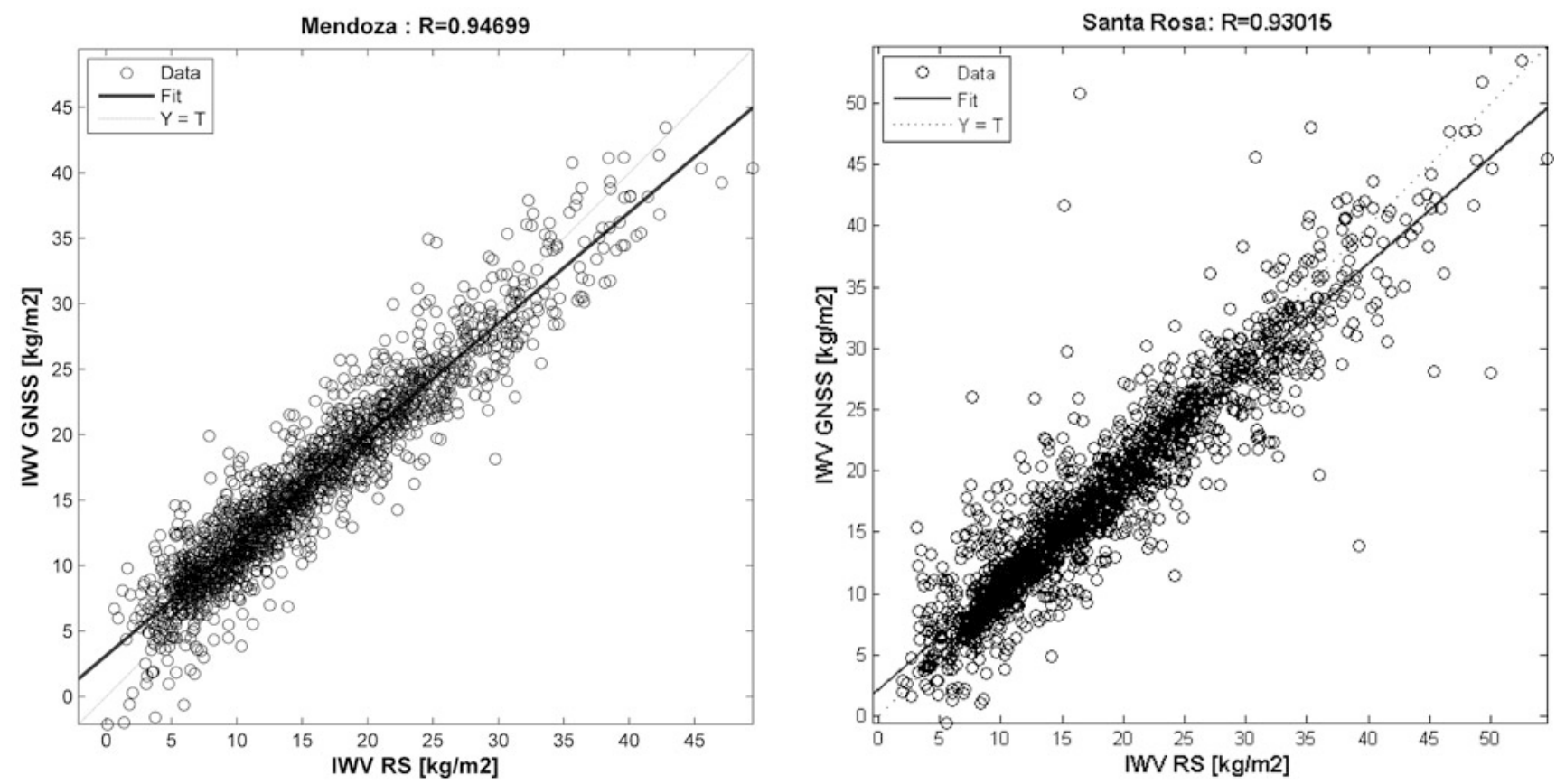

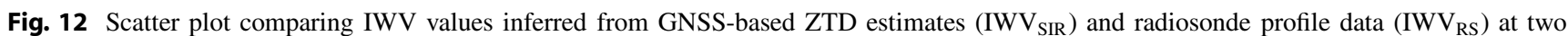
selected SIRGAS stations (Jan 2014 to Dec 2018)

et al. (1994) and Douša and Vaclavovic (2014). However, we must work to obtain a product in near real time (with $90 \mathrm{~min}$ of latency), applying ultra-rapid orbits and clocks, or even better using real-time corrections (Guerova et al. 2016).

The publication of this new product from SIRGAS opens the opportunity for new research topics that can be carried out both continentally and regionally in Latin America. As an example, it has been shown that SIRGAS ZTD products can be used to calculate the IWV over SIRGAS stations, thus providing IWV with a spatial and temporal density not existing in Latin America by conventional techniques. This variable has also been validated with radiosonde data (mean correlation coefficient 0.89 , in 10 compared sites). SIRGAS ZTD products can be used as a reference for 
different scientific applications (e.g. validation of regional numerical weather prediction reanalyses) and they could be used for monitoring trends and variability in atmospheric water vapour in Latin America region, similar than EUREF Permanent network (Pacione et al. 2017).

Acknowledgments The authors are grateful for the silent task of those responsible for the GNSS stations, the data centers and the SIRGAS analysis centers (CHL, DGF, ECU, IBG, IGA, LUZ, URY and UNA), without which this research could not have been carried out.

The ERA-Interim data used were provided by ECMWF. Radiosonde data were provided by Wyoming Weather Web, University of Wyoming.

\section{References}

Askne J, Nordius H (1987) Estimation of tropospheric delay for microwaves from surface weather data. Radio Sci 22:379-386. https://doi.org/10.1029/RS022i003p00379

Berg H (1948) Allgemeine Meteorologie. Dümmler's Verlag, Bonn, p 337

Bevis M, Businger S, Chiswell S, Herring TA, Anthes RA, Rocken C, Ware RH (1994) GPS meteorology: mapping zenith wet delays onto precipitable water. J Appl Meteorol 33:379-386

Bianchi CE, Mendoza LPO, Fernández LI, Natali MP, Meza AM, Moirano JF (2016) Multi-year GNSS monitoring of atmospheric IWV over central and South America for climate studies. Ann Geophys 34:623-639

Boehm J, Niell AE, Tregoning P, Schuh H (2006a) Global mapping function (GMF): a new empirical mapping function based on numerical weather model data. Geophys Res Lett 33:25. https://doi.org/10. 1029/2005GL025546

Boehm J, Werl B, Schuh H (2006b) Troposphere mapping functions for GPS and very long baseline interferometry from European Centre for Medium-Range Weather Forecasts operational analysis data. J Geophys Res 111:B02406. https://doi.org/10.1029/2005JB003629

Bonafoni S, Mazzoni A, Cimini D, Montoponi M, Pierdicca N, Basili P, Ciotti P, Carlesimo G (2013) Assessment of water vapor retrievals from a GPS receiver network. GPS Solut 17(4):475-484

Brunini C, Sánchez L, Drewes H, Costa S, Mackern V, Martínez W, Seemuller W, da Silva A (2012) Improved analysis strategy and accessibility of the SIRGAS reference frame. In: Kenyon S, Pacino M, Marti U (eds) Geodesy for planet earth. International association of geodesy symposia, vol 136. Springer, Berlin, pp 3-10

Bruyninx C, Legrand J, Fabian A et al (2019) GNSS metadata and data validation in the EUREF permanent network. GPS Solut 23:106. https://doi.org/10.1007/s10291-019-0880-9

Byram S, Hackman C, Tracey J (2011) Computation of a high-precision GPS-based troposphere product by the USNO. In: Proceedings of the 24th international technical meeting of the satellite division of the institute of navigation (ION GNSS 2011). 2001

Byun SH, Bar-Sever YE (2009) A new type of troposphere zenith path delay product of the international GNSS service. J Geod 83(3-4):1-7

Calori A, Santos JR, Blanco M, Pessano H, Llamedo P, Alexander P, de la Torre A (2016) Ground-based GNSS network and integrated water vapor mapping during the development of severe storms at the Cuyo region (Argentina). Atmos Res 176-177:267-275

Camisay MF, Rivera JA, Mateo ML, Morichetti PV, Mackern MV (2020) Estimation of integrated water vapor derived from global navigation satellite system observations over Central-Western Argentina
(2015-2018). Validation and usefulness for the understanding of regional precipitation events. J Atmos Sol Terr Phys 197:105143. https://doi.org/10.1016/j.jastp.2019.105143. ISSN 1364-6826

Chen G, Herring TA (1997) Effects of atmospheric azimuthal asymmetry on the analysis of space geodetic data. J Geophys Res 102:20,489-20,502

Cioce V, Martínez W, Mackern MV, Pérez R, De Freitas S (2018) SIRGAS: reference frame in Latin America. Coordinates XIV(6):610. ISSN 0973-2136

Dach R, Lutz S, Walser P, Fridez P (2015) Bernese GNSS software version 5.2. Astronomical Institute, University of Bern, Bern. https:// doi.org/10.7892/boris.72297. ISBN: 978-3-906813-05-9; Open Publishing

Davis JL, Herring TA, Shapiro I, Rogers AE, Elgened G (1985) Geodesy by interferometry: effects of atmospheric modeling errors on estimates of base line length. Radio Sci 20:1593-1607

Douša J, Vaclavovic P (2014) Real-time zenith tropospheric delays in support of numerical weather prediction applications. Adv Space Res 53:1347-1358. https://doi.org/10.1016/j.asr.2014.02.021

Fernández LI, Salio P, Natali MP, Meza AM (2010) Estimation of precipitable water vapour from GPS measurements in Argentina: validation and qualitative analysis of results. Adv Space Res 46:879894

Guerova G, Jones J, Douša J, Dick G, de Haan S, Pottiaux E, Bock O, Pacione R, Elgered G, Vedel H, Bender M (2016) Review of the state of the art and future prospects of the ground-based GNSS meteorology in Europe. Atmos Meas Tech 9:5385-5406. https://doi. org/10.5194/amt-9-5385-2016

Hunter JD (2007) Matplotlib: a 2D graphics environment. Comp Sci Eng 9(3):90-95

Llamedo P, Hierro R, de la Torre A, Alexander P (2017) ENSO-related moisture and temperature anomalies over South America derived from GPS radio occultation profiles. Int J Climatol 37:268-275

Mendes VB (1999) Modeling the neutral-atmosphere propagation delay in radiometric space techniques. Ph.D. dissertation, Department of Geodesy and Geomatics Engineering Technical Report No 199, Univ. of New Brunswick, Canada

Pacione R, Araszkiewicz A, Brockmann E, Dousa J (2017) EPNRepro2: a reference GNSS tropospheric data set over Europe. Atmos Meas Tech 10:1689-1705. https://doi.org/10.5194/amt-101689-2017

Rüeger JM (2002) Refractive index formula for radio waves. In: Proc. XXII FIG Int. Congr., April 19-26, 2002, Web. http://www.fig.net/ resources/proceedings/fig_proceedings/fig_2002/Js28/JS28_rueger. pdf

Saastamoinen J (1973) Contributions to the theory of atmospheric refraction. Bull Geod 107:13-34. https://doi.org/10.1007/ BF02521844

Sánchez L, Drewes H, Brunini C, Mackern MV, Martínez-Díaz W (2015) SIRGAS core network stability. In: Rizos C, Willis P (eds) IAG 150 years. International Association of Geodesy Symposia, vol 143. Springer, Cham, pp 183-191

Van Baelen J, Aubagnac JP, Dabas A (2005) Comparison of nearreal time estimates of integrated water vapor derived with GPS, Radiosondes, and microwave radiometer. J Atmos Ocean Technol 22:201-210

Wang J, Zhang L, Dai A, Van Hove T, Van Baelen J (2007) A nearglobal, 2-hourly data set of atmospheric precipitable water dataset from ground-based GPS measurements. J Geophys Res 112:D11107. https://doi.org/10.1029/2006JD007529

Weber G, Mervart L, Stürze A, Rülke A, Stöcker D (2016) BKG Ntrip Client, Version 2.12. Mitteilungen des Bundesamtes für Kartographie und Geodäsie, vol 49. Frankfurt am Main, 2016 
Open Access This chapter is licensed under the terms of the Creative Commons Attribution 4.0 International Licence (http://creativecommons. org/licenses/by/4.0/), which permits use, sharing, adaptation, distribution and reproduction in any medium or format, as long as you give appropriate credit to the original author(s) and the source, provide a link to the Creative Commons licence and indicate if changes were made.

The images or other third party material in this chapter are included in the chapter's Creative Commons licence, unless indicated otherwise in a credit line to the material. If material is not included in the chapter's Creative Commons licence and your intended use is not permitted by statutory regulation or exceeds the permitted use, you will need to obtain permission directly from the copyright holder.

(c) (i) 